\title{
THE FEEDING OF THE FIVE HUNDRED THOUSAND: CITIES AND AGRICULTURE IN EARLY ISLAMIC MESOPOTAMIA
}

\author{
By HUGH KENNEDY
}

This paper discusses the impact of the foundation of major cities in Mesopotamia in the early Islamic period (c. 636-900 CE) and their impact on the agricultural economy and rural settlement in the area. It considers the potential agricultural productivity of the area, the availability of river transport, the fiscal structure of the early Islamic state and the way in which it created demand for foodstuffs, and the development of the qați ${ }^{c} a$ as a form of landholding which provided security of tenure and hence the encouragement of long-term investment in agricultural infrastructure.

The first two centuries after the Islamic conquest saw the foundation of a number of new towns in Iraq, notably Basra, Kufa and, above all, Baghdad. ${ }^{1}$ These new towns were of enormous importance politically, economically and culturally to the emerging Islamic state and, without them, the early Muslim world would have looked very different. Although the three cities were different in many ways, they shared two common characteristics. The first was that, with the possible exception of the old Sasanian capital at Ctesiphon/al-Madā'in, they were vastly larger than any of the small towns of the preceding period. Furthermore, they were also much bigger than the Basra and Baghdad of the eleventh and twelfth centuries CE. Not until the late twentieth century did either of these cities attain the population levels of the early Islamic period. Such precocious and exuberant urban development clearly demands some historical scientific investigation.

Estimates of the population of Baghdad at the height of its prosperity in the late eighth and ninth centuries suggest that it is likely to have been half a million or more. ${ }^{2}$ The figure of eighty thousand given for the number of muqātila fighters settled in Basra in the years after its foundation in 636 suggest a population of at least $250,000 .^{3}$

In this paper I will argue that the development of these very large cities was the result of four different political social and economic factors, which together formed a sort of virtuous circle. All four were essential to this extraordinary pattern of urban growth. The first was the agricultural potential of the lands of Greater Mesopotamia, ${ }^{4}$ a potential that was largely unrealized until activated by man-made irrigation systems. The second was the river system, which permitted the transport of large quantities of grain and other foodstuffs. The third was the social and fiscal structure of the early Islamic state, which led to the emergence of a large body of people who were paid cash salaries by the administration and as such generated demand for supplies of all sorts. The fourth and final element was the working out of a legal framework for landownership, which gave individuals security of tenure (at least in theory) and encouraged them to invest in projects of agricultural expansion. These factors will now be considered in turn.

\footnotetext{
${ }^{1}$ For the Muslim conquest of Iraq, F. M. Donner, The Early Muslim Conquests (Princeton, 1981) 157-220. The best introduction to the social and economic history of Iraq in this period remains M. Morony, Iraq after the Muslim Conquest (Princeton, 1984).

${ }^{2}$ The best discussion of the size and population of the city remains J. Lassner, The Topography of Baghdad in the Early Middle Ages (Detroit, 1970) 158-60. He suggests a built-up area of some 7,000 hectares (compared with an estimated 540 hectares for Ctesiphon and 1,400 hectares for Constantinople intra muros) with a population of at least 280,000 ,
}

adding that "a figure twice that does not seem altogether impossible".

${ }^{3}$ The muqātila were the troops of the early Islamic state, paid pensions and enrolled in the diwans. For the numbers see al-Balādhurī, Ansäb al-ashräf iv pt. a, ed. M. Schloessinger (Jerusalem, 1970) 190.

${ }^{4}$ For the purposes of this article, Greater Mesopotamia includes the area of modern Iraq, but also the valleys of the Middle Euphrates and its tributaries (notably the Khabur and Balikh) now within the borders of modern Syria, and the plains of Khuzistan, now in modern Iran. 


\section{Agricultural fertility}

The lands of Greater Mesopotamia, ${ }^{5}$ if properly irrigated and managed, could attain a productivity which could be found nowhere else in the Islamic world. Estates in the alluvial lands of the Sawad of Iraq and the riverain areas of the Euphrates valley areas could be extremely profitable for those who owned them, supporting a gracious and cultivated life in palace and city. Rough calculations based on early ${ }^{c} A$ bbasid revenue lists suggest that the alluvial lands of southern Iraq generated four times as much tax revenue as the next richest area of the Islamic world, Egypt, and five times as much as all of Syria and Palestine combined. ${ }^{6}$ This intensive agriculture was almost entirely dependent on artificial irrigation. Apart from some areas in the piedmont of the Zagros mountains, there were no areas where people could rely on the $200 \mathrm{~mm}$ of rainfall per year which would sustain dry farming. Basra in the south only has an average of $60 \mathrm{~mm}$ per year: without irrigation, these lands would be as arid and desolate as the desert which separates them from Syria and Palestine.

There were substantial volumes of water not only in the Tigris and Euphrates but in the smaller rivers like the Khabur and Diyala which flowed into them. But while the quantity of water was reasonably reliable, the irrigation system needed constant investment and maintenance. In this environment, almost all major irrigation was gravity fed. This meant that water had to be carried in canals which were higher than the surrounding land. This in turn meant that the system was highly vulnerable: breaches in the banks would cause water to flood out into the fields and be lost. There were other hazards. If the gradient were not steep enough, silt would be deposited on the bottom of the canal and would have to be re-excavated at great expense. If the gradient were steep enough, the river would scour itself but the pressures on the banks would be more urgent. And then, as the cultivators of Basra were to find in the third/ninth century, there was the issue of salinization; lack of proper drainage would result in the build-up of salts on the surface of the soil so that even the back-breaking labour of thousands of black Zanj slaves could not restore it to fertility.

We should contrast this with agricultural systems in other Middle Eastern environments. In the rain-fed, dry-farming environments of the coastal plains of Syria and Palestine, or further inland on the hills of the Massif Calcaire, the Hawran or the mountains of Moab, agriculture can never be as productive as it can be in Mesopotamia. On the other hand it is much less vulnerable to financial and political stress. No investment is needed to bring the rain, though small-scale ditches and dams may help to distribute it more usefully. These areas can support subsistence farming at periods when outside markets are stagnant or dying. In cases of prolonged disruption, the population has the option of shifting the emphasis of their agricultural endeavours to pastoralism.

Or consider the pre-High Dam agriculture of the Nile Valley in Egypt. This was of course absolutely dependent on the rise and fall of the river. A good Nile flood would bring prosperity and abundant food, a poor Nile would result in starvation and misery, but no amount of money or government intervention could influence the height of the river. Equally a bad year could easily be followed by a good. In the canal-based agricultural systems of Mesopotamia, the destruction of a major canal might take years to repair, during which time the inhabitants might move elsewhere or revert to the more secure economic refuge of a nomadic lifestyle.

As Adams noted, the late Sasanian period saw the expansion of the agricultural area to the maximum that physical geography and existing irrigation techniques would allow: despite the settlement of many Arab Muslim troops and the emergence of new urban communities after the Islamic conquest, there is no evidence of the subsequent expansion of agriculture and settlement in such well-established farming environments as the Diyala basin. ${ }^{7}$

There was one area in which the trauma of the Islamic conquests seems to have had a direct impact on the landscape and that was the Bata'ih or marshes of southern Iraq. According to

${ }^{5}$ For an overview of the irrigation landscapes of Iraq, T. J. Wilkinson, Agricultural Landscapes of the Near East (Tucson, 2003) 71-99. For the agricultural environment of the Diyala basin in the pre-modern period see R. McC. Adams, The Land behind Baghdad (Chicago, 1965) 3-20; also R. McC. Adams and H. J. Nissen, The Uruk Countryside: the Natural Setting of Urban Societies (Chicago, 1972) and R. McC. Adams, Heartland of Cities: Surveys of Ancient Settlement and Land Use on the Central Floodplain of the Euphrates (Chicago, 1981). For a general overview of agricultural practice based on textual sources, H. Q. El-Samarraie, Agriculture in Iraq in the Third Century A.H. (Beirut, 1972).

${ }^{6}$ See H. Kennedy, "The decline and fall of the first Muslim empire", Der Islam 81 (2004) 3-30 at pp. 11-12.

${ }^{7}$ Adams, Land behind Baghdad 69-83. 
al-Balādhurī ${ }^{8}$ who gives the fullest account to be found in the Arabic sources, the marshes were first formed in the reign of the Sasanian Shah Kubādh (488-531) when the Tigris burst its banks and large areas of fertile land were flooded. Kubādh, the historian says, was too feeble to do anything about it, but when his son Khusraw I Anushirvan (531-79) succeeded he ordered that the dykes (musannahāt sing. musannah) be restored and some of the land was brought back under cultivation. Then in the time of Khusraw II (591-628), towards the end of his long reign, the waters of the Tigris and Euphrates rose higher than they had ever done before or since and numerous breeches were made in the banks. The king struggled to block the gaps up, filling forty in one day. He also brought money and spent it extravagantly but his efforts were in vain against the water. In the years of chaos which immediately preceded the Arab invasions the Persians were too busy fighting to block up the breaches and anyway, with the collapse of the central power, the local dihqans lacked the resources to undertake such major work.

The Umayyad caliph Mưāwiya b. Abī Sufyān (41-60/661-80) decided to take action and appointed a mawlä ${ }^{9}$ of his, ${ }^{\mathrm{c}} \mathrm{Abd}$ Allāh b. Darrāj, to reclaim the flooded land, and he restored land which generated a revenue (ghalla) of five million dirhams per year. Later on al-Hajjāj is said to have neglected the maintenance of the rivers as a move against the dihqans, ${ }^{10}$ whom he suspected of sympathizing with the rebel leader Ibn al-Ash'ath. Some years after Ibn al-Ash'ath's revolt had been put down in 82/701, al-Hajjaj wrote to the caliph al-Walīd b. ${ }^{c} A b d$ al-Malik saying three million dirhams were required to repair the breaches. Al-Walīd thought that was too much but his brother Maslama b. 'Abd al-Malik, who was always on the look-out for economic opportunities, agreed to put up the money if he could have any low-lying land which was still flooded as a qatīc $a$. He thus gained possession of a number of districts which lay beside each other and dug a canal known as al-Sībayn to drain the land. Farmers and sharecroppers then entrusted their lands to him because of his prestige. ${ }^{11}$

There were, however, marginal areas which could be brought under cultivation, if the economic conditions were favourable, with the investment of large sums of money in irrigation schemes. Among these areas were the Middle Euphrates valley ${ }^{12}$ and the valleys of its tributaries, the Khabur and Balikh. ${ }^{13}$ These were areas where settlement had been very sparse in Late Antiquity, not least because they lay in the disturbed and ravaged areas between the Byzantine and Sasanian empires. Another area which could be developed in very favourable circumstances was the lands in the desert areas which surrounded the Islamic new town of Basra to the west of the Shatt al-Arab. In the early Islamic period (c. 640-900 CE) these areas showed a richness of cultivation and an intensity of rural settlement seen neither before nor since.

\section{River transport}

The second important factor was the use of river transport. There is no detailed description of river transport and, as often, we have to rely on anecdotal evidence to piece together a picture of river transport during this period. ${ }^{14}$ Texts make it clear that river boats were a normal way of moving both people and goods. For example, in 184/800 the ${ }^{c}$ Abbasid caliph Hārūn al-Rashīd came to Baghdad, travelling there from Raqqa on the Euphrates "in ships" ( fi'l-sufun).$^{15}$ In $187 / 803$ we find Hārūn in a boat (zaw) on the Euphrates at al-'Umr, planning the fall of the Barmakids. ${ }^{16}$ There

\footnotetext{
${ }^{8}$ Aḥmad b. Yahyā al-Balādhurī, Futūḥ al-buldān, ed. M. J. de Goeje (Leiden, 1866) 292-93.

${ }^{9}$ mawlā (pl. mawälī) in this period means a non-Arab Muslim, usually attached as a client to an Arab individual or tribe.

${ }^{10}$ Landowners, mostly of Iranian origin.

${ }^{11}$ al-Balādhurī, Futūh 294.

12 For agriculture in the Middle Euphrates valley, S. Berthier et al., Peuplement rural et aménagements hydroagricoles dans la moyenne vallée de l'Euphrate, fin $V I I^{e}-X I X^{e}$ siècle (Damascus, 2001).

${ }^{13}$ On the Balikh valley, see $\mathrm{K}$. Bartl, Frühislamische Besiedlung im Balih-TallNordsyrien (Berlin, 1994) and K.
}

Bartl, "Balih Valley Survey. Settlements of the late Roman/ early Byzantine and Islamic period" in Continuity and Change in Northern Mesopotamia from the Hellenistic to the Early Islamic Period, ed. K. Bartl and S. Hauser (Berlin, 1996) 333 48. On the Khabur, H. Kühne, " Zur historischen Geographie am Unteren Habur", Archiv für Orientforschung 26 (1979) 181-95.

${ }^{14}$ For a further discussion of the importance of river transport for the supply of the new city of Baghdad, see below.

${ }^{15}$ Muhammad b. Jarīr al-Tabarī, Ta'rikkh al-rusul wa't$m u l \bar{k} k$, ed. M. J. de Goeje et al. (Leiden, 1879-1901) iii 649.

${ }^{16}$ al-Tabarī, Ta'rīkh iii 682. 
is also evidence of ports: according to the geographer al-Iștakhrī, Balis was the "port (furda) of the people of Syria on the Euphrates". ${ }^{17}$ At Qarqisiya the fruits from the town and from the Khabur valley were collected for shipping to Iraq in the winter. ${ }^{18}$ According to Yāqūt, the Khabur from Ra's al-'Ayn to the Euphrates at Qarqisiya had at one time been used for navigation. People had used small zawäriq or sufun to visit their gardens and orchards along the river bank. ${ }^{19}$

Another insight into the importance of river transport on the Euphrates can be found in the account of the founding of the city of Rahba. ${ }^{20}$ Rahba was a new town founded during the reign of Hārūn al-Rashīd by a Bedouin chief turned property-developer by the name of Mālik $b$. Tawq al-Taghlibī. A rahba is described as a low-lying area overlooked by higher ground, often with stagnant water in it, which can be made very fertile. According to an old man from Rahba the story of its foundation went like this:

Hārūn al-Rashīd was travelling along the Euphrates in a harrāqa before reaching a shadhā. ${ }^{21}$ With him were some boon-companions, including Mālik b. Tawq. When they were approaching the water-wheels Mālik said, "O Commander of the Faithful, why not get out on to the shore to get by this spot (buqca)?" and Hārūn al-Rashīd said to him, "I think you are afraid of these water-wheels," so Mālik b. Tawq replied, "May God preserve the Commander of the Faithful from every danger. But if the Commander of the Faithful agrees (then he should do it). If not, the choice is his," and al-Rashid said, "Your words have frightened me," so he brought the ship (safina) alongside and got up on to the shore. When the boat reached the place of the waterwheels it spun around and then overturned with everything that was in it. Hārūn was amazed by this and prostrated himself to God in thanks and ordered that money be brought and given to the poor everywhere, and he said to Mālik, "Ask what you want and it will be done for you," and Mālik replied, "May the Commander of the Faithful give me in this place some land on which I can build a city which will be named after me. Hārūn replied, "I have already done it," and ordered that he be helped in the construction with money and men.

The anecdote goes on to tell the story of how Mãlik was almost executed for defying the caliph but saved his life by the recitation of a suitable and moving poem, but what is interesting here is that the story shows the use of the river for transportation and irrigation. Mālik wants to build his city by the river on land which can be irrigated. The site of Rahba is well known and the ${ }^{\mathrm{c}} \mathrm{Abbasid}-$ period city did indeed lie beside the river in a place with no natural fortifications. River access and fertile land were Malik's priorities. In the eleventh or twelfth centuries the riverside site was effectively abandoned and the habitation moved to a less exposed site on the edge of the desert escarpment, and a magnificent castle, whose ruins still dominate the area today, was constructed.

The Tigris was also used for river trade. Ibn Hawqal describes Jazirat Ibn Umar (modern Cizre) as the "port (furda) of Armenia, the Byzantine lands and the districts of Mayyafariqin and Arzan, and boats (marākib) go from there to Mosul laden with goods like honey, cooking-butter (samn), cheese, walnuts, almonds, hazelnuts, raisins and figs." 22

The river systems to the south of Baghdad were equally important for transportation. Numerous anecdotes make it clear that boats were the normal way of moving people and goods between Basra, Wasit and Baghdad. Again, most of our information comes from anecdotal sources. Consider the career of the great tax-farmer, Hāmid b. al-'Abbās, during the caliphate of al-Muqtadir (295$320 / 908-32$ ). His wealth derived from his tax farms in the Wasit area, but it was the availability of water transport that meant he could bring provisions to Baghdad and enabled him to become an important figure in the caliphate. He had storehouses in Baghdad where grain could be kept until the price was high enough, when it was sold at the harbour ( $f u r d a$ ) on the river. ${ }^{23}$ When he travelled from Wasit to Baghdad, "he signalled his departure by trumpet blast. Then he made all his retainers

\footnotetext{
${ }^{17}$ Ibrāhīm b. Muhammad al-Iștakhrī, al-Masālik wa'lmamälik, ed. M. J. de Goeje (Leiden, 1927) 62. Again, most of our information comes from anecdotal sources.

${ }^{18}$ Abū'l-Qāsim Ibn Hawqal, Kitāb șürat al-ard, ed. J. H. Kramers (Leiden, 1939) 227.

${ }^{19}$ Yãqūt al-Hamawī, Muljam al-buldān s.v. Ra's al-'Ayn.

${ }^{20}$ For the archaeology and early history of the site, T. Bianquis, "Rahba et les tribus arabes avant les croisades",
}

Bulletin d'études orientales 41-42 (1993) 23-52.

${ }^{21}$ Two types of boats in regular use in the early ${ }^{\mathrm{c}} \mathrm{Abbasid}$ period, the harräqa being smaller than the more barge-like shadhā.

${ }^{22}$ Ibn Hawqal, Sürat al-arḍ 225.

${ }^{23} \mathrm{Abu}{ }^{\mathrm{C} A} \mathrm{~A} \overline{\mathrm{i}}$ Miskawayh, Tajāib al-umam, ed. H. F. Amedroz and D. S. Margoliouth (London, 1921) i 74-75, 100. 
and dependents embark in launches and barges ... his horses and those of his attendants and followers being led on the bank." ${ }^{24}$

\section{The fiscal system}

The third element in the compound was the fiscal system of the early Islamic state. ${ }^{25}$ This is not the place to give a full account of this system but some main points can be emphasized. In the immediate aftermath of the conquest of Iraq, the incoming Arab-Muslim soldiers were concentrated in a small number of urban settlements rather than allowed to disperse through the agricultural lands of the Sawad. ${ }^{26}$ This entailed the abandonment of their pastoral or agricultural lifestyles, and the settlers came to depend for their subsistence on a cash 'aț $\bar{a}$ paid by the state once or twice a year. Originally there were also some payments in kind (oil, wheat etc.) known as rizq, but by the beginning of the second/eighth century at the latest these payments had all been replaced by cash. The salaries were usually paid in urban centres where the soldiers and others entitled to them were registered in the diwān. Such cities were known as mişr (pl. amşār). The effect of this was to create a large class of urban, salaried individuals with money to spend on basic foodstuffs and a regular and reliable demand for agricultural products. As noted above, evidence suggests that the population of Basra had reached 250,000 within a generation of the conquest and the establishment of the city. All these people would need to eat at least once a day and many of them had money to pay for their food: a massive market was created. The foundation of Baghdad by the ${ }^{\mathrm{c}} \mathrm{Abbasid}$ caliph al-Manșūr in 145/762 intensified this process, for the Khurasani troops from eastern Iran who had brought the dynasty to power, as well as other elements of the military and the bureaucracy, were settled in the city and paid cash salaries. With its huge population, the Baghdad of the third/ninth century generated a massive demand, whose gravitational pull was felt throughout the area of Greater Mesopotamia and beyond.

\section{Landholding}

The fourth and final element in this virtuous circle was the development of the qațit $a$ (pl. qața $\left.{ }^{\prime} i^{c}\right)^{27}$ as a form of landholding. ${ }^{28}$ Again, this is not the place for a complex discussion of this institution but a few points might be emphasized. The qatt $\bar{l}^{2} a$ was developed by early Islamic legal authorities to regularize the private ownership of landed estates and properties. The nature of the settlement of the Arab-Muslims in the conquered lands led to the argument that the cultivated lands in these areas should remain in the possession of those who were already cultivating them, but that the yield of these properties should be considered as the fay' of the Muslims in that area, a communal resource which should be held for the benefit of all. The jurist Abū Yūsuf explained the situation, "CUmar's ${ }^{29}$ decision not to distribute the land amongst those who had captured it was guided by God's book and was of benefit to all Muslims. The taxes collected from such lands enabled the payment of pensions and wages from this perpetual income, thus making the wars of $j i h \bar{a} d$ possible and providing security against the recapture of their lands and places by enemies." 30

There was, however, a continuing demand for private property from rich and powerful men in the early Islamic state. Early Islamic law was nothing if not creative in its approach to solving problems and by the early Umayyad period the qați $a$ had emerged as a legal framework for private landholding. The idea underlying the concept of qați $a$ was that dead land (mawãt), brought under cultivation usually by irrigation but also by drainage or the clearing of brush, should become the

\footnotetext{
${ }^{24}$ Miskawayh, Tajärib i 94-95.

${ }^{25}$ For a fuller development of this argument, $H$. Kennedy, "Military pay and the economy of the early Islamic state", Historical Research 75 (2002) 155-69.

${ }^{26}$ On the earliest Arab military settlement in Iraq, Morony, Iraq 236-53.

${ }^{27}$ qati $i^{\mathrm{c}} a$ is frequently translated as "fief", e.g. by P. Hitti in his translation of al-Balādhurī's Futüh al-buldān and A. Ben Shemesh, Abu Yusuf's Kitab al-kharaj, but a fief, meaning a conditional or time-limited grant, is precisely what it is not.

${ }^{28}$ There is very little discussion of qati $a$ in the secondary
}

literature and no entry in the Encyclopaedia of Islam. For the classic discussion of the fiscal status of qața ${ }^{\prime} i^{\mathfrak{c}}$, Abū Yūsuf, Kitāb al-Kharäj trans. A. Ben Shemesh (Leiden, 1969) 73-77, and Abū 'Ubayd al-Qāsim Ibn Sallām (d. 223 AH), Kitāab $a l-A m w \bar{a} l$, ed. M. K. Haras (Cairo, 1975), English trans. I. A. $\mathrm{K}$. Nyazee, The Book of Revenue (Reading, 2002) paras. 676-727. See also below, the discussion of qata $\bar{a} l^{\mathrm{i}}$ in the Basra area, which shows how the system could work in practice.

${ }^{29}$ CUmar b. al-Khațtāa, second caliph, 13-23/634-44.

${ }^{30}$ Ábū Yūsuf, Kităb al-kharāj 68. 
property of the person or persons who had made it productive. It was held in absolute ownership and was alienable (it could be sold) and heritable.

Although there remained some discussion about the tax status of such property, it was generally held that it should pay the tithe ( $\left.{ }^{c} u s h r\right)$ rather than the higher kharäj (land-tax) paid on most agricultural land. As Abū Yūsuf notes, " $u$ ushr only is charged on qața ${ }^{\prime}{ }^{c}$ when the granted lands require investment for digging canals, erecting farm buildings and other heavy expenses for the farming of the granted qaț $a$." ${ }^{31}$ Such qaț ${ }^{\prime} i^{c}$ were developed by people rich enough to invest substantial funds in making the land productive. The qați $a$ gave the landowner security of tenure which would give him the confidence to develop the land. These tax-breaks, combined with the regular and consistent demand for foodstuffs from developing urban centres, made investing in agricultural development a very attractive proposition. We shall see below how the device of the qaț $\bar{t}^{\mathrm{T}} a$ played a major role in developing the food supply of Basra, and there is less clear, but still persuasive evidence, that it was important in the feeding of Baghdad as well.

After the consideration of these general trends I would like to turn now to two areas in which, I believe, the interaction of textual and archaeological evidence can show how these systems worked in practice. The first of these is the agricultural hinterland of the Muslim new town of Basra in the south of Iraq, and the second is the lands of the Middle Euphrates and its tributaries, the Khabur and the Balikh, which supplied Baghdad.

\section{Basra $^{32}$}

Despite some evidence of minor Sasanian settlement in the area, Basra was essentially an Islamic new town founded, it is said, by 'Utba b. Ghazwān in 17/638 to house the Arab army, which was then engaged in the conquest of southern Iraq, Khuzistan and Fars. The reasons for the choice of this particular site are obscure. It lay some fifteen kilometres from the Shatt al-Arab and therefore had no direct access to the maritime trade of the Gulf; the pre-Islamic port of Ubulla (ancient Apologos) on the banks of the river would seem to have been a much more logical location for the new settlement. Neither the textual nor the archaeological records suggest that the city when founded had an extensive agricultural hinterland. Furthermore, it clearly lacked adequate and reliable supplies of drinking water.

Despite these apparent disadvantages, the role of the city as a mişr where salaries were paid to the troops meant that the financial drawing-power of the settlement proved sufficient, at least for a couple of centuries, to overcome the natural disadvantages of the situation. As we have seen, the population seems to have grown very rapidly. All these people had to be fed, and human ingenuity and investment had to compensate for the natural disadvantages of the site.

The result was a major campaign of investment in new irrigation projects in the land between the city and the Shatt al-Arab, which is described in considerable detail in al-Balādhurīs Futüh albuldān. ${ }^{33}$ This account, which has barely been studied by historians, is of very great importance. It is the only account we have from Iraq of property ownership and land development in the first century of Islam. From a legal-historical point of view, it expands on and largely corroborates the legal texts on the nature of $q a t^{\tau} \bar{a}$ grants. From an economic-historical angle, it shows how the existence of the new town encouraged a new class of entrepreneurs to invest in large-scale agricultural entrerprises. As usual in classical Arabic historiography, the argument is advanced by means of anecdote and oratory. According to one story, al-Ahnaf $b$. Qays explained to the caliph 'Umar $b$. al-Khattāb that, while Muslim settlers in other areas were established in already cultivated areas with "sweet waters and luxuriant gardens", the people of Basra only had "reedy sabkha (salt marsh)

\footnotetext{
${ }^{31}$ Abū Yūsuf, Kitāb al-kharāj 73.

${ }^{32}$ L. Massignon, "Explication du plan de Basra" in Westöstliche Abhandungen R. Tschudi (Wiesbaden, 1954) 154-74; Salih al-'Ali, "Khitat al-Basra", Sumer 8 (1952) 72-83, 281303; C. Pellat, Le milieu basrien et la formation de Gahiz (Paris, 1953).
}

\footnotetext{
${ }^{33}$ For an important discussion of al-Balādhurì's text on the development of the Basra region, Wadad al-Qadi, "The names of estates in the state registers before and after the Arabization of the diwans" in Umayyad Legacies: Medieval Memories from Syria to Spain, ed. A. Borrut and P. Cobb (Leiden, 2010) 255-80.
} 
which never dries up and where pasture never grows, bounded on the east by brackish (ujajj) water and on the west by waterless desert $\left(a f l \bar{a}^{\prime}\right)$. We have no cultivation or stock farming to provide us with our livelihood and food, which comes to us as through the throat of an ostrich ${ }^{34}$ If a weak man goes out to find drinking water he has to go for two farsakhs. If a woman goes to fetch it, she has to tie up her children by the neck, as goats are tied up, for fear of being attacked by enemies or eaten by lions. If you do not take away our misery and end our destitution, we shall all perish."

According to the narrative, this finely crafted piece of rhetoric had its effect: the caliph ordered that the people of Basra should be paid the ' $a t \bar{a}^{\prime}$ and wrote to the governor, Abū Mūsā al-Ash'arī, ordering him to dig a canal (nahr). ${ }^{35}$ Despite its anecdotal character, the story makes important points. The provision of water required the digging of canals and was linked to the payment of the ' $a t a \vec{a}$. The alleged involvement of the caliph in person is characteristic of such anecdotes, showing that the great 'Umar himself regarded the provision of water as part of the function of government.

The digging of canals was very expensive. A canal to bring drinking-water from the Batīha marshes to Basra was estimated to cost 300,000 dirhams, but the project was deemed to be so important that the governor who was sponsoring it said that he would, if necessary, use all the tax revenues of Iraq on it. There is some indication that black Zanj slaves were beginning to be used for development projects in this area and minor Zanj revolts are recorded in 70/689-90 and 75/694. ${ }^{36}$ The buying, feeding and managing of large numbers of slaves would certainly have been expensive but it is more likely that most of the labour was done by free men serving for wages. In either case, the digging of irrigation canals was a very substantial investment and such investment could only be made in the expectation of a reliable return. This could only have been obtained from the market for food in Basra. Major projects, especially the provision of drinking-water, were sometimes undertaken by governors, but in the majority of cases the land was assigned by the governor but the initiative and investment seem to have come from private individuals and families, who no doubt regarded such enterprise as a good investment for themselves and their descendants.

In the following pages, al-Balādhuri gives much detailed information about the digging of canals. ${ }^{37}$ Abū Mūsã dug what became known as the Ubulla canal from the Shatt al-Arab to Basra. Maintenance of these watercourses was a constant struggle and much of Abū Mūsā's canal had to be re-excavated by Ziyād $b$. Abī Sufyān, the governor during the reign of the caliph Uthmān $b$. 'Affān (23-35/644-56). At the same time, 'Umar ordered Abū Mūsā to dig the Ma'qil canal, though other traditions suggest, plausibly, that it was constructed by Ziyād b. Abī Sufyān in the reign of $\mathrm{Mu}^{\mathrm{c} a}$ wiya. The Macil canal led water from the Euphrates to the town and allowed boats with supplies from the rest of the Sawad to reach the city, while to the south the Ubulla canal connected it with the Shatt al-Arab. These important civil-engineering projects not only provided water for the city but also allowed boats carrying goods and provisions to reach it.

The obligation of the government to provide drinking-water is confirmed in an anecdote set at the end of the Umayyad period in the reign of the caliph Yazid b. al-Walid (126/744). The citizens of Basra approached the governor of Iraq complaining that their water was salty. They presented him with two samples in glass bottles (qärüratayn), one containing water of Basra and the other water from the Batiha marshes further to the north, and asked that he dig a canal so that they could have the sweet Batīha water to drink. The governor wrote to the caliph explaining the problem and Yazid wrote back saying that a canal should be dug "even if the expense of this canal is equal to all the tax revenues we receive from Iraq". ${ }^{38}$ Even this did not solve the problem because the new canal just delivered a meagre trickle, and complaints about the salty water led the "Abbasid governor, Sulaymān b. ${ }^{c} A \bar{i}$, to spend a million dirhams on dams to direct more water into the new canal. ${ }^{39}$

\footnotetext{
${ }^{34}$ The throat of an ostrich being particularly narrow; E. W. Lane, Lexicon, s.v. mara'a.

${ }^{35}$ al-Balādhurī, Futūh 356-57.

${ }^{36}$ A. Popovic, "al-Zandj" in Encyclopaedia of Islam, 2nd edn, xi 445-46.

${ }^{37}$ Wadad al-Qadi has demonstrated that these detailed accounts come from Qaḥham b. Sulaymān (d. after
}

158/774), whose grandfather had been captured in Isfahan and become a mawla (client) of the family of Abū Bakra al-Thaqafi, one of the most important families in the early history of the city (al-Qadi, "Names of estates" 261-65).

${ }^{38}$ al-Balādhurī, Futūh 370.

${ }^{39}$ al-Balādhurī, Futūh 370-71. 
The Macqil and Ubulla canals provided the framework of Basra's connection with the waterways of Iraq but they were followed by numerous other, smaller-scale projects. The reasons for this burst of activity were various. Canal developments were often named after the developer who had them dug and the resultant prestige and reputation were certainly important. When ${ }^{\mathrm{c}} \mathrm{Abd}$ Allāh $\mathrm{b}$. ${ }^{\mathrm{A}} \overline{\mathrm{A}} \mathrm{mir}$ returned from campaigning in Khurasan to find that his deputy in Basra, Ziyād, had restored the Ubulla canal, he was furious, accusing Ziyād of wanting the fame and reputation (shahr and dhikr) which he would have earned. ${ }^{40}$ But Ziyād also lost out. He was largely responsible for the excavation of the $\mathrm{Ma}^{\mathrm{c}}$ qil canal but the canal became known after the eponymous $\mathrm{Ma}^{\mathrm{c}}$ qil, whose connection with the project was very tenuous. The narrative describes how Ziyād sent a man with a thousand dirhams to travel the length of the watercourse and ask everyone he met who was the sāhib of the canal and give the money to anyone who said "Ziyād". As he feared, the man came back with the money unspent and Ziyād knew he had lost the battle, ${ }^{41}$ and, indeed, the modern port of Basra is known to this day as Macqil, while the great Ziyād is nowhere commemorated in the place names of the area.

There were more tangible benefits to be derived from the digging of canals. As one contemporary observed when visiting Ibn "Āmir, who had just opened a new canal, "I have not seen any canal which is more of a blessing (baraka) than this one. The weak are able to get water out of it at the doors of their houses and their food supplies are brought to their homes." 42

The passage brings out two important reasons for the digging of canals. One was the providing of water for domestic purposes (and also, presumably, for ablutions in the mosques and for the baths of the city). But the most important reason was to bring land into cultivation. Repeatedly, the process is described as the granting of a qaț $\bar{l}^{c} a$ and the digging of a canal. ${ }^{\mathrm{c}} \mathrm{Abd}$ Allāh b. "Āmir, for example, gave his half-brother ${ }^{\mathrm{c}} \mathrm{Abd}$ Alläh $\mathrm{b}$. 'Umayr an estate of eight thousand jarībs "and dug for it the canal which is known as the Nahr Ibn 'Umayr". ${ }^{43}$ When Bashshār b. Muslim al-Bāhilī gave al-Hajjāj a particularly fine carpet, the governor gave him an estate "and dug this canal (Nahr Bahshsār) for it". ${ }^{44}$ Proper drainage could dramatically increase the value of a property. The "island" which lay between the Macqil and Ubulla canals was at first largely sabkha. At one stage the caliph $\mathrm{Mu}^{c} \bar{a}$ wiya gave part of this area to one of his nephews as a qați ${ }^{c} a$. When the gilded youth arrived to inspect his new possession, the crafty Ziyād arranged for it to be flooded. When the Umayyad saw it he said, "the Commander of the Faithful has given me a marsh (batīha) which is no use to me." Ziyād bought it from him for 200,000 dirhams, dug canals in it and made it into qața $i^{c}$ (aqța minha). Whether he then sold off the qat $\bar{a}^{\prime} i^{c}$ or gave them as rewards to family and supporters is not stated but the whole deal was clearly thought to be very advantageous. ${ }^{45}$

The canal could become the centre of a more urban development: when Bilāl $b$. Burda dug the canal which bore his name, he set up shops (hawānit ț) on both sides of it and transferred the süq there. ${ }^{46}$ Fish may have been another source of profit from canals for two of the newly dug waterways were known after the types of fish to be found in them. ${ }^{47}$ One canal was known as the Canal of the Mills ${ }^{48}$ while the Canal of Dubays was named after a man who used the water for fulling cloth (he is described as a qașsār $){ }^{49}$

This process of investment was encouraged by the nature of landholding in the area. The newly irrigated areas were almost all held as qața $\bar{a}^{\prime} i^{c}$. They were held as qați $\imath^{i} a$ because they were on previously dead land which was brought into cultivation by the digging of irrigation canals. It was a condition of holding a qati $\tau^{c} a$ that it was developed: Ziyad is said to have made this explicit by declaring to one grantee, "I have only granted (anfahdu) what you have cultivated ('ammaratum)." Al-Madā'inī then goes on to explain, "he would give a man a qațic $a$ and allow him two years and if he brought it under cultivation (he could keep it) but if not, he would take it away." ${ }^{50}$ In short, if you wanted to have a qațic $a$, you had to irrigate it or you would lose it.

40 al-Balādhurī, Futūh 357

41 al-Balādhurī, Futūh 358

42 al-Balādhurī, Futūh 359

43 al-Balādhurī, Futūh 359

44 al-Balādhurī, Futūh 361

${ }^{45}$ al-Balādhuri, Futūh 361
${ }^{46}$ al-Balādhurī, Futūh 364.

47 al-rā' in Nahr al-Rā' (al-Balādhurī, Futūh 361) and jubāra (al-Balādhurī, Futūh 363).

${ }^{48}$ al-arhā', al-Balādhurī, Futūh 362.

49 al-Balādhurī, Futūh 358.

50 al-Balādhurī, Futūh 363. 
The doctrine that whoever irrigated the land owned it was occasionally put to the test. In one case a certain Bashīr b. ' Ubayd Allāh irrigated an area of land, digging a main canal, ditches (sawāq $\bar{l})$ and cross-canals ( $m u^{c}$ taridat $t$ ) in order to take possession of the land. The only problem was that it was actually owned by someone else, Hilāl b. Ahwaz al-Māzinī, who had been given the land, all eight thousand jaribs of it, as a qați $a$ by the caliph Yazīd b. Mucãwiya (60-64/680-83). His son al-Himyarī then brought a law-suit against Bashīr (khāsamahu). He was in luck: Bashīr had criticized the governor of Iraq, Khālid b. 'Abd Allah al-Qasrī, for wrongdoing and Khālid had heard about it. Rather than asking the $q \bar{a} d \bar{l}$ to adjudicate, Khālid wrote to the man in charge of the ahdāth of Basra, ordering him to give al-Himyarī a free hand over the newly dug canal. ${ }^{51}$ In another case Yazīd $b$. al-Muhallab dug a canal on a qați $a$ belonging to ${ }^{c} U$ bayd Allāh $\mathrm{b}$. Abī Bakra and tried to pressure 'Ubayd Allah's son into writing a deed (kitäb) acknowledging his rights over the watercourse, but the son refused and threatened to take him to court. ${ }^{52}$

Once they had been granted, $q a t \bar{a}^{\prime} i^{c}$ were held in absolute ownership. They could be swapped, sold or inherited. One anecdote makes the hereditary nature of this tenure explicit. In it the caliph Yazīd b. ${ }^{~}$ Abd al-Malik (101-5/720-4) realizes that he has no property in the area and orders his governor of Iraq, 'Umar b. Hubayra, to go there and take any of the qața $\bar{i}^{c}$ which are left over $(f u d \bar{u} l)$. The governor duly went there and began investigating and measuring the estates. When he came to one property and asked to whom it belonged, the owner (săhib) replied, "to me". When asked why it was his he responded with a couplet of poetry,

We inherited it from our true fathers
And shall bequeath it when we die to our sons.

Eventually, the scale of the opposition among the qaț ${ }^{2} a$ holders forced 'Umar to abandon the project. $^{53}$

Further evidence for the hereditary nature of the $q a t^{2} a$ is to be found in the story of the estate known originally as Muhallabān, ${ }^{54}$ belonging to al-Mughīra, son of the great Muhallab b. Abī Sufra. Like the rest of the family's property it had been confiscated after the fall of Yazīd $b$. alMuhallab (102/720). With the coming of 'A bbasid rule, it was restored to Sufyān b. Mucāwiya b. Yazid al-Muhallab but his claim was challenged by other members of the family. They brought a case against him (khāsamahu), claiming that al-Mughïra had died before his father. Half of the estate was inherited by his daughter, Sufyān's mother, but, under Islamic law, the other half reverted to his father. The claimants were prepared to accept Sufyān's right to inherit his mother's half but argued that the rest of the estate (i.e. the portion which had reverted to al-Muhallab) should rightfully be theirs. Sufyann retorted that al-Mughira had a son as well but the claimants pointed out that he had no rights over this portion because the son was only his maternal uncle. Sufyān, now a powerful man in the service of the ${ }^{\mathrm{c}} \mathrm{Abbasids}$, was able to brush their claims aside, refusing to give them any part of the 1,600 jari $\bar{b}$ estate, and his family still owned the land at the time when al-Balādhuri was writing (c. 290/902). The importance of this story for our purposes does not lie in the detail of the inheritance dispute, which is not entirely clear, but in the unequivocal evidence that the qaț $a$ was regarded as a bit of property which should be inherited and, if necessary, divided up among the heirs. ${ }^{55}$

The text also provides direct evidence of the selling of $q a t^{\prime}{ }^{\prime} i^{c}$. Dhāt al-Hifăfayn, for example, was sold by ${ }^{\mathrm{C}} \mathrm{Abd}$ al-Raḥmān $\mathrm{b}$. Abī Bakra, who was said to have been the first child to be born in Basra after the settlement of the site, ${ }^{56}$ to ${ }^{~}$ Arabī al-Tammār, mawlā of his sister Amat-Allah. ${ }^{57}$ The property known as Shatt 'Uthmān was named after 'Uthmān b. Abĩ̄l 'Āṣ al-Thaqafi, who had bought it from

\footnotetext{
${ }^{51}$ al-Balādhurī, Futūh 364 . The passage is very interesting on the little-understood function of the sähib al-ahdāth, who functions here as the governor's enforcer in the city.

52 al-Balādhurī, Futūh 365 . The final phrase of this short anecdote, which deals with possible legal proceedings, does not seem to make sense.

${ }^{53}$ al-Balādhurī, Futūh 366.
}

\footnotetext{
${ }^{54}$ For the importance of these "-ān" names as indicators of ownership see al-Qadi, "Names of estates" 269-77.

${ }^{55}$ al-Balādhurī, Futūh . Sufyān was a ruthless operator: it was he who had the great Ibn al-Muqaffa ${ }^{c}$ tortured to death.

${ }^{56}$ al-Balādhurī, Futūh 347

${ }^{57}$ al-Balādhurī, Futūh 367.
} 


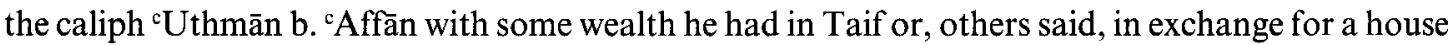
in Madina which the caliph wished to incorporate in the mosque. ${ }^{58}$

One advantage of this was that the owners of qața $i^{\prime}$ enjoyed a favourable tax regime. As long as the lands were "dead" (mawāt) and not subject to existing fiscal obligations, they could pay the much lower șadaqa ( $\left.{ }^{c} u s h r\right)$ rate. In the case of Basra, the key text is the letter ${ }^{59}$ alleged to have been written by the caliph 'Umar b. al-Khatțāb to al-Mughīra $b$. Shucba, governor of Basra, enjoining him

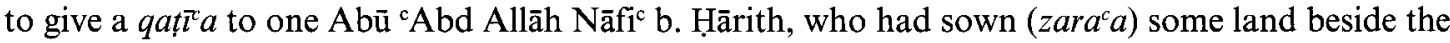
Tigris in the area of Basra and raised horses there. He was to be allowed possession of the land as long as it was not subject to existing taxation (jizya) of the land of the Persians (al-acajim) or supplied with water from land which was paying taxes. The use of the word jizya is significant here. It is clearly used to mean the land-tax which would later be known in Islamic law as kharajj, and its use in this context suggests that the document is genuinely archaic. It also suggests that the early Muslims in this area were simply taking over Persian land classifications. The word qaț $a$ is not used here; the governor is simply ordered to let $N a \mathrm{f}^{\mathrm{c}} \mathrm{i}^{\mathrm{C}}$ have possession of the land and to help him, but the principle that someone who brings land under cultivation should have possession of it is clearly enunciated. Elsewhere in the text it is clearly stated that the grant was a $q a t^{\tau} a$ and that it was one of only two $q a t \bar{a}^{\prime} i^{c}$ granted in Basra by the caliph ' ${ }^{\circ}$ mar b. al-Khațāab, the other one being given to Abū Bakra. There seem, however, to have been some exceptions to this benign fiscal regime. The Nahr Jacfar belonging to $\mathrm{Ja}^{\mathrm{c}}$ far, mawla of Salm b. Ziyād, is specifically described as kharäjiyan, that is, liable to kharäj tax. Why this should have been so is not stated and it was clearly regarded as an exception. ${ }^{60}$

Most of the canals and $q a t \bar{a}^{\prime} i^{c}$ are named after individuals and take the form of Nahr Fulān or Fulānān. The survival of these names in al-Balādhurī's work enables us to develop a profile of the landowning class in the Basra area in the first century and a half of Muslim rule. According to the author the first canal was dug to Basra by Abū Mūsā al-Ash'arī on the instructions of the caliph 'Umar, but this left no trace in the toponymy of the area and it may be no more than a pious legend. The first major wave of development was undertaken during the governorates of cAbd Allāh $b$. 'Āmir (29/649-50 until 35/656 and 41/661 until 44/664). "Abd Allāh certainly enriched his family as well as himself, giving his half-brother ${ }^{\mathrm{c}} \mathrm{Abd}$ Allah $\mathrm{b}$. ${ }^{\mathrm{C}} \mathrm{Umayr}$, as we have seen, an enormous qatti $a$ of eight thousand jari $\bar{b} s$, the largest recorded in the Basra area. ${ }^{61}$ The most important figure in this campaign was Ibn 'Āmir's deputy and successor, Ziyād b. Abī Sufyān (45/665-53/673). It seems to have been he who completed the $\mathrm{Ma}^{\mathrm{c}}$ qil and Ubulla Canals, which were the backbone of the Basra system. Not surprisingly, his relatives and mawäli were among the beneficiaries of his activity. His son Abū Bakra owned property and there was a special qați $\bar{l}^{2} a$ called al-Banāt which belonged to his daughters. ${ }^{62}$ His daughter Umm Habīb had a canal named after her. ${ }^{63}$ Important properties were also owned by his sāhib al-shurța (chief of police), Makhūl, and two of his mawälī, Fīl and Mismār. ${ }^{64}$

Another family which benefited were the descendants of Abū Bakra Nufay ${ }^{c} \mathrm{~b}$. Masrūh (died $c$. 52/672), a former slave from Taif who had famously let himself down from the city wall on a pulley (bakra, hence, allegedly, his unusual name) to join Muhammad and achieve his freedom. He had been one of the first settlers in Basra, and he and his seven sons became rich from their ownership of baths in the city and powerful from their close relationship with Ziyād. It was ${ }^{\mathrm{c}} \mathrm{Abd}$ al-Rahmān b. $A b i$ Bakra who was in charge of engineering the extension of the Ubulla canal to Basra. When he broke the dam to allow the water into the new canal, he galloped his horse beside the flowing water and it advanced almost faster than he could ride. ${ }^{65}{ }^{2} \mathrm{Abd}$ al-Rahmān also inherited the qați $a$ of al-

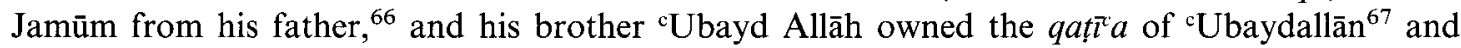
Suwaydān, named after a man to whom he gave it. ${ }^{68}$ In the next generation, his son Salm b. ${ }^{\text {CUbayd }}$

\footnotetext{
58 al-Balādhurī, Futūh 362.

59 al-Balādhurī, Futūh 351.

${ }^{60}$ al-Balādhur̄̄, Futüh 367.

${ }^{61}$ al-Balādhurī, Futūh 359.

62 al-Balādhurī, Futüh 361, 363.

63 al-Balādhurī, Futū 358.
}

\footnotetext{
${ }^{64}$ al-Balādhurī, Futūh 362, 364.

${ }^{65}$ al-Balādhurī, Futūh 357.

${ }^{66}$ al-Balādhurī, Futüh 362

${ }^{67}$ al-Balādhurī, Futūh 362

${ }^{68}$ al-Balādhurī, Futūh 365.
} 
Allāh had the canal known as Nahr Salm but under the early ${ }^{\mathrm{C}}$ Abbasids the fortunes of the family declined somewhat. Al-Manșūr confiscated some of their properties and in 160/776-77 al-Mahdi rejected their pretensions to an Arab genealogy but accepted their claims to be mawāli of the Prophet, adding that all those who accepted this reclassification would be entitled to a share of the family's property in Basra, while those who did not would be excluded. Not surprisingly, all except three accepted the judgment, a genealogical humiliation in exchange for property. ${ }^{69}$ The story illustrates how the property remained in family hands for at least a century and a half after Abū Bakra originally developed it.

Other important Basran families owned qața ${ }^{\prime} i^{c}$ in the area, notably the Muhallabis and the family of the conqueror of Transoxania, Qutayba b. Muslim al-Bāhili, who owned the Qutaybatān..$^{70}$ But there were also numerous less prominent Arab families from Basra which had one of more canals or $q a t \bar{a}^{\prime} i^{c}$ named after them. These presumably form the group which al-Balādhurī refers to as the elite (sarāh sing. sari or ashräf sing. sharī $f$ ) of Basra. ${ }^{71}$ We also find women owning such properties, apparently in their own right. One such was the already mentioned Umm Habīb b. Ziyād. 'A Abd Allāh b. 'Āmir had a canal called the Nahr Umm ${ }^{c}$ Abd Allāh Dajjāja dug and named it after his mother, ${ }^{72}$ and another canal was named after his daughter-in-law, Humayda, wife of his son ${ }^{\mathrm{A}} \mathrm{Abd}$ al-'Az̄̄z. ${ }^{73}$

There were also a number of mawālī who developed their own properties: Fayrūz, mawlā of Banū Thaqīf who dug Nahr Fayrūz, Azraq b. Muslim, a mawlā of Banū Hanīfa who owned Azraqān, Ziyād, mawlä of Banū Haytham who owned Ziyadān and others. ${ }^{74}$ There were other groups of non-Arabs. The Asāwira, Persian elite soldiers who had defected to the Muslims at the time of the conquests, are credited with developing a canal known as Nahr Asāwira, apparently in partnership with ${ }^{\mathrm{c}} \mathrm{Abd}$ Allah $\mathrm{b} .{ }^{\mathrm{c}} \overline{\mathrm{A}} \mathrm{mir} .{ }^{75}$ Alongside them was a group of Isfahanis who migrated to Basra and purchased land from some of the Arabs there, probably converting to Islam at the time. ${ }^{76}$

The chronology of this economic development is fairly clear from al-Balādhurī's account. There is only one reference to pre-Islamic irrigation works in the area, a canal and a qassr belonging to al-Nu'mān b. al-Mundhir, the last King of Hira (580-602), which had been given to him as a qați $a$ in the days of Kisra (i.e. the late Sasanian period). Significantly, it seems to have been situated on the banks of the Tigris, not in the immediate vicinity of new Islamic Basra. ${ }^{77}$ The development began extremely rapidly after the first settlement of Islamic Basra. It would seem that the major irrigation works had been completed by the death of Ziyād b. Abī Sufyān in about 53/674. New developments continued to be undertaken at a slower pace throughout the Umayyad period as families like the Muhallabids and the family of Qutayba $b$. Muslim sought to consolidate their position in the city. The early 'Abbasid period saw some new works. Al-Manșūr's mawlā Abū'l-Khāșîb gave his name to a canal and al-Manșūr himself is explicity said to have dug a canal which became known as the canal of the Amīr (al-Mu'minīn). Sulaymān b. 'Alī, ' ${ }^{\circ}$ bbasid governor of Basra, also undertook some new works. ${ }^{78}$ These seem to have been the last projects of their sort and there is no further evidence for those individual and family initiatives which had driven so much of the earlier investment in irrigation. Al-Rashīd and the Barmakids certainly owned property in the area, ${ }^{79}$ but there is no record of further development. No new $q a t \bar{a}^{\prime} i^{c}$ are recorded after the end of the Umayyad period and this form of landowning gradually became extinct.

This intensive agricultural activity has left significant traces in the archaeological record. In the early 1960s, a very distinctive irrigation landscape was detected to the south and west of the modern city of Basra. ${ }^{80}$ The system occupied an enormous area of some 57,000 hectares lying between the old westerly course of the Euphrates, now completely abandoned, and the Shatt al-Arab. In 1962 just eight thousand of these hectares were used for the cultivation of date-palms along the Shatt

${ }^{69}$ al-Tabarī, Ta'rikkh iii 477-82.

${ }^{70}$ al-Balādhurī, Futūh 363.

${ }^{71}$ al-Balādhurī, Futūh 361, 370.

${ }^{72}$ al-Balādhurī, Futüh 359.

${ }^{73}$ al-Balādhurī, Futüh 360.

${ }^{74}$ al-Balādhurī, Futüh 361, 362.

${ }^{75}$ al-Balādhurī, Futūh 358.
${ }^{76}$ al-Balādhurī, Futūh 366.

${ }^{77}$ al-Balādhurī, Futūh 363 .

${ }^{78}$ al-Balādhurī, Futū h $h$ 362-63.

79 al-Balādhurī, Futūh 362-63.

${ }^{80}$ See H. S. Nelson, "An abandoned irrigation system in southern Iraq", Sumer 18 (1962) 67-72. 
al-Arab: the rest had reverted to desert. The area is characterized by a regular pattern of low, straight ridges, about two metres high, separated by hollows. The ridges are very saline with a salt crust up to twenty centimetres thick; nothing grows there. There is less salt in the hollows and a sparse population of salt-resisting plants can survive there. Clearly the traces represent the remains of a very extensive irrigation system, now almost completely abandoned and saline.

Fresh water might have been brought to the system from the Euphrates, as was typical in many Mesopotamian irrigation systems. On the other hand it might have come from the Shatt al-Arab. When the tide rose in the Gulf, twice a day, the fresh water in the Shatt al-Arab was backed up and the fresh-water level raised sufficiently for it to enter the system. One other point should be noted: the irrigated area lay immediately to the south of the site of the old city of Basra, which was, in the late seventh and eighth centuries, one of the two largest cities in Iraq and possibly in the whole Muslim world.

How then are we to understand this ridge and furrow environment? Nelson suggests that we are looking at an artificial irrigation system which was increasingly rendered unusable by salinization produced by a system which lacked sufficient gradient to produce the flow of drainage to carry the salts away. In order to counter this, salty topsoil was removed and piled on to the ridges. The scale of the undertaking is breathtaking. Nelson calculates that some forty-five million tons of soil were shifted.

We cannot be certain about the historical background of these extraordinary labours but we can suggest a plausible hypothesis. The system is undated and we have no potsherds or other diagnostic features which would enable us to make confident statements. However, there is no indication of any pre-Islamic irrigation works in this area. The only settlement was the port city of Ubulla/ Apologos, which never seems to have been a large urban centre. Furthermore, much of the area was probably formerly under the waters of the Gulf, which had by this time receded to the south. The balance of probability, therefore, is that we are looking at a system developed in the early Islamic period, when the investment was made viable by the presence of the nearby Muslim metropolis of Basra.

The enormous amount of labour required to bring this land into cultivation and to keep it clear of salt deposits has already been noted. Nelson calculates that if each man shifted two tons of soil a day (which seems a very optimistic estimate, given the extreme heat and lack of shelter in which they would have been working) the "work done on the abandoned system would represent nearly a decade of effort by 25,000 men". 81

The narrative sources make it clear that it was in the area of southern Mesopotamia that the $\mathrm{Zanj}^{82}$ were employed as labourers. Zanj is the term given to the black inhabitants of the west coast of Africa. It is not clear when they first began to appear in southern Iraq or on what terms they came, but it is likely that they were imported as slaves for the great works undertaken in the Umayyad period. It was clearly extremely unpleasant work and the slaves soon expressed their resentment. As already mentioned, there was a minor rebellion as early as 70/689-90 and another, more serious one in $75 / 694$, both suppressed by the Umayyad authorities. In $255 / 869$ a still more serious and widespread revolt began and lasted until the final defeat of the rebels in 270/883. In this case al-Tabari records that the rebels were employed as navvies (kassāhin $)$ removing the nitrous topsoil ( $s i b \bar{a} k h)$ and putting it into piles to make the lands of the Shatt al-Arab region cultivable. This report is exactly reflected in the evidence on the ground.

If this reconstruction of the process is generally correct, we can see how the coming of early Islamic rule had a major effect on the landscape of the Shatt al-Arab area. The first cause was the foundation of the city of Basra and its rapid growth. All these new inhabitants needed to be fed, for they had abandoned their pastoral lives and were not given farming land on which they could maintain themselves. Furthermore, these men were in receipt of government salaries $\left({ }^{c} a t \bar{a}\right)$ and had, so to speak, money to spend. It was natural therefore that entrepreneurs would invest in the expansion

${ }^{81}$ Nelson, "Abandoned irrigation system" 71.

${ }^{82}$ On the Zanj see A. Popovic, The Revolt of African Slaves in the 3rd/9th Century (Princeton, 1998); H. Kennedy,
"Caliphs and their chroniclers in the middle Abbasid period" in Texts, Documents and Artefacts: Islamic Studies in Honour of D. S. Richards, ed. C. F. Robinson (Leiden, 2003) 17-35. 
of agricultural land in the vicinity and a whole irrigation system would be developed. In the medium term, however, the new system was unsustainable. Lack of adequate drainage led inevitably to salinization of the soil and attempts to keep the salts at bay were doomed to failure. Furthermore, Basra, sacked by the Zanj rebels and later by the Qaramita, ${ }^{83}$ was no longer the lucrative market it had been in early Islamic times. There was no economic incentive to restore the cultivation of the area. It became a relict landscape, marked by the traces of this moment of agricultural expansion but never brought under the plough again. From the late fourth/tenth century Basra itself shifted and a new city, still called Basra, developed on the banks of the Shatt al-Arab, where it stands today, and the old site was abandoned to the desert, only a few old and venerated tombs remaining to mark the spot.

\section{Baghdad}

My second case study is based on the food supply system of Baghdad. The foundation and development of Basra had a major impact on the agriculture of the surrounding area but its effect seems to have been fairly localized. The impact of the foundation of Baghdad by contrast was much more widespread. The city was founded by the 'Abbasid caliph al-Manșūr in 144-45/762 as an administrative centre and base for the ${ }^{\mathrm{A}} \mathrm{Abbasid}$ army. This army, which may have amounted to some forty thousand men, was largely recruited in Khurasan in north-east Iran and hence the men had neither homes nor livelihoods in Iraq. ${ }^{84}$ They may have been fewer in number than the muqätila of early Islamic Basra but they were probably paid more, receiving monthly salaries (as opposed to ${ }^{\prime} a t \bar{a}$ ' once or twice a year) with which to support themselves and their families. While the area was not completely uninhabited, Baghdad was essentially a new town; there was no existing city in the area and hence no agricultural hinterland or system to supply a dense urban population.

The growth of the city was prodigious. As noted above, modern calculations suggest that in the ninth century the total built-up area was around seven thousand hectares, five times the size of contemporary Constantinople and thirteen times the size of the Sasanian capital at Ctesiphon. It is likely that the population of this vast metropolis was at least 500,000 and it may well have been more. ${ }^{85}$ As has already been mentioned, this massive increase in the urban population does not seem to have been matched by a concomitant expansion of agricultural land in the Diyala plains, the immediate agricultural hinterland of the city; indeed the available evidence suggests that the total area under cultivation actually decreased from some eight thousand square kilometres in late Sasanian times to six thousand square kilometres in the early Islamic period.

The problems of supplying the city are discussed in the Arabic texts which describe its foundation. In these accounts, al-Manșür is shown explaining how the city is to be provisioned. He lays great emphasis on the suitability of the site as the centre of a network of water communications: "here is the Tigris with nothing between us and China, so everything which comes by sea can reach us by the river, as can the provisions (mira) from the Jazira, Armenia and the surrounding areas. And there is the Euphrates on which everything from Syria, Raqqa and the surrounding areas may come. ${ }^{" 86} \mathrm{He}$ then pitched his camp by the Sarat canal, one of the major waterways which led from the Euphrates to the Tigris. In another passage, the caliph explains the economic and political importance of ensuring adequate supply networks. While he was looking for a site for his new capital, he was recommended a place called Bārimmā, which was said to be agreeable and salubrious. The caliph spent the night there but in the morning rejected the site: "it will not sustain the army, the notables $(a l-n \bar{a} s)$ and the social groupings $\left(a l-j a m \bar{a}^{c} \bar{a} t\right)$. I want only a place which people will find suitable: by conforming to their needs it will conform to mine. Prices should not go high there and provisioning (al-macuna) should not be difficult. If I settled in a place where anything could not be imported by land and sea, prices would rise, supplies ( $m \bar{a} d a$ ) would be in short supply and provisioning would be burdensome." 87

\footnotetext{
${ }^{83}$ The Qaramita (or Carmathians) were a group of Bedouin Ismaili Shi'ites who dominated the Syrian desert for much of the early fourth/tenth century.

${ }^{84}$ For the numbers see $\mathrm{H}$. Kennedy, The Armies of the Caliphs (London, 2001) 97-99.
}

\footnotetext{
${ }^{85}$ For the area and population of the city, Lassner, Topography 155-60.

${ }^{86}$ al-Tabarī, Ta'rikkh iii 272.

${ }^{87}$ al-Ṭabarī, Ta'rikh iii 273.
} 
In this narrative he went back to the site of Baghdad which he had already noticed saying, "This is the site on which I shall build. Supplies $(a l-m \bar{a} d a)$ can arrive by the Euphrates, the Tigris and a network of canals. Only a place like this will support the army and the general populace ('amma)." 88 The local dehquan (landowner) explained the advantages of the site in commercial terms: "You, $\mathrm{O}$ Commander of the Faithful, will be situated on the Sarat canal. Provisions (al-mira) from the west will come to you on ships (sufun) by way of the Euphrates, as will luxury goods (tarä'if) from Syrian and Egypt. Provisions ( al-mira) will come to you by ship (sufun) from China, India, Basra and Wasit up the Tigris and from Armenia and the lands contiguous to it by the Tāmarrā canal until it reaches the Zab. Provisions from Byzantine territory, Amid, the Jazira and Mosul will come to you down the Tigris," and he then went on to point out the defensive advantages of a site surrounded by rivers and canals which will be "moats (khanädiq) for the Commander of the Faithful's city" ${ }^{89}$ Of course it is impossible to be certain that such dialogues took place but we can be sure that they reflect the thinking of the caliph and his advisers and how later generations saw the advantages of the site of Baghdad.

The continuing importance of the Tigris for the supply of Baghdad is revealed in an account of the wars which resulted in the take-over of Baghdad by the first of the Buyid rulers, Mucizz al-Dawla in 334/946. The Hamdanid Nāșir al-Dawla, who was effectively ruler of Mosul and the grain-growing areas of the Jazira, was fiercely opposed to the Buyid. His troops confronted the Buyids on the west bank of the Tigris at Baghdad and the local farmers had their crops seized by his soldiers. At the same time he resorted to economic warfare. On the east bank, where Nāssir al-Dawla had installed himself, "bread was sold for five ratls a dirham (that is very cheap) because barges brought flour from Mosul". On the west bank, by contrast, bread was very expensive: "this was because Nasir alDawla prevented imports from Mosul coming to the western side". ${ }^{90}$

The effects of the rapid growth of Baghdad can be seen in the Euphrates valley. Recent archaeological work has produced evidence of substantial agricultural expansion in the middle Euphrates area, where new canals were built to irrigate the riverain plains and new villages founded. Between 1987 and 1990 a team led by Sophie Berthier conducted surveys and limited excavations in the middle Euphrates valley, between Deir ez-Zor and the Iraqi border at Abu Kamal. The results, published in 2001, ${ }^{91}$ are extremely impressive and provide a fascinating insight into the agricultural life of this area. Three of the survey's plans that illustrate the expansion in settlement in the Umayyad and 'Abbasid periods are republished here (Figs. 1-3).

Most of this area of the Euphrates valley enjoys between 100 and $150 \mathrm{~mm}$ of rain per year, with perhaps a bit more in the north-west. ${ }^{92}$ This is well short of the $200 \mathrm{~mm}$ which is the lowest rainfall that permits dry farming. Any agricultural activity is therefore based on irrigation. The river flows through a valley which might be as wide as fifteen kilometres in some places but is much narrower in others. On each side of the valley rise plateaux, that of Syria to the west and the Jazira to the east. The height of the escarpment means that raising water from the river to the level of the plateau is out of the question. Agriculture is only possible in the floor of the valley between the river and the escarpments.

In places norias are used nowadays to raise water and of course mechanical pumps provide a means to supply water to the fields. In early Islamic times, however, large-scale irrigation required the construction of canals to take water from the river or its tributaries so that it flowed at the level of a metre or two above the surrounding fields. Gravity could then be used to lead the water from the main canal into subsidiary irrigation ditches and thence to the fields. These canals, flowing as they do between artificial dykes above the level of the valley floor, require constant maintenance, both to prevent the channel from silting up and to keep the dykes from being breached. This agriculture could be very productive but it was investment-intensive, requiring constant and sustained expenditure. Only in certain rare and favourable circumstances could it be undertaken.

In the lower half of the length of the river surveyed by Berthier and her team, there was no evidence of large-scale irrigation, and settlement in the early Islamic period was limited to a handful

${ }^{88}$ al-Tabarī, $\dot{T} a^{\prime} r i \bar{k} h$ iii $273-74$.

89 al-Ṭabarī, Ta'rīkh iii 275.

${ }^{90}$ Miskawayh, Tajārib ii 91

\footnotetext{
91 Berthier, Peuplement (n. 12).

${ }^{92}$ Berthier, Peuplement map p. 175.
} 


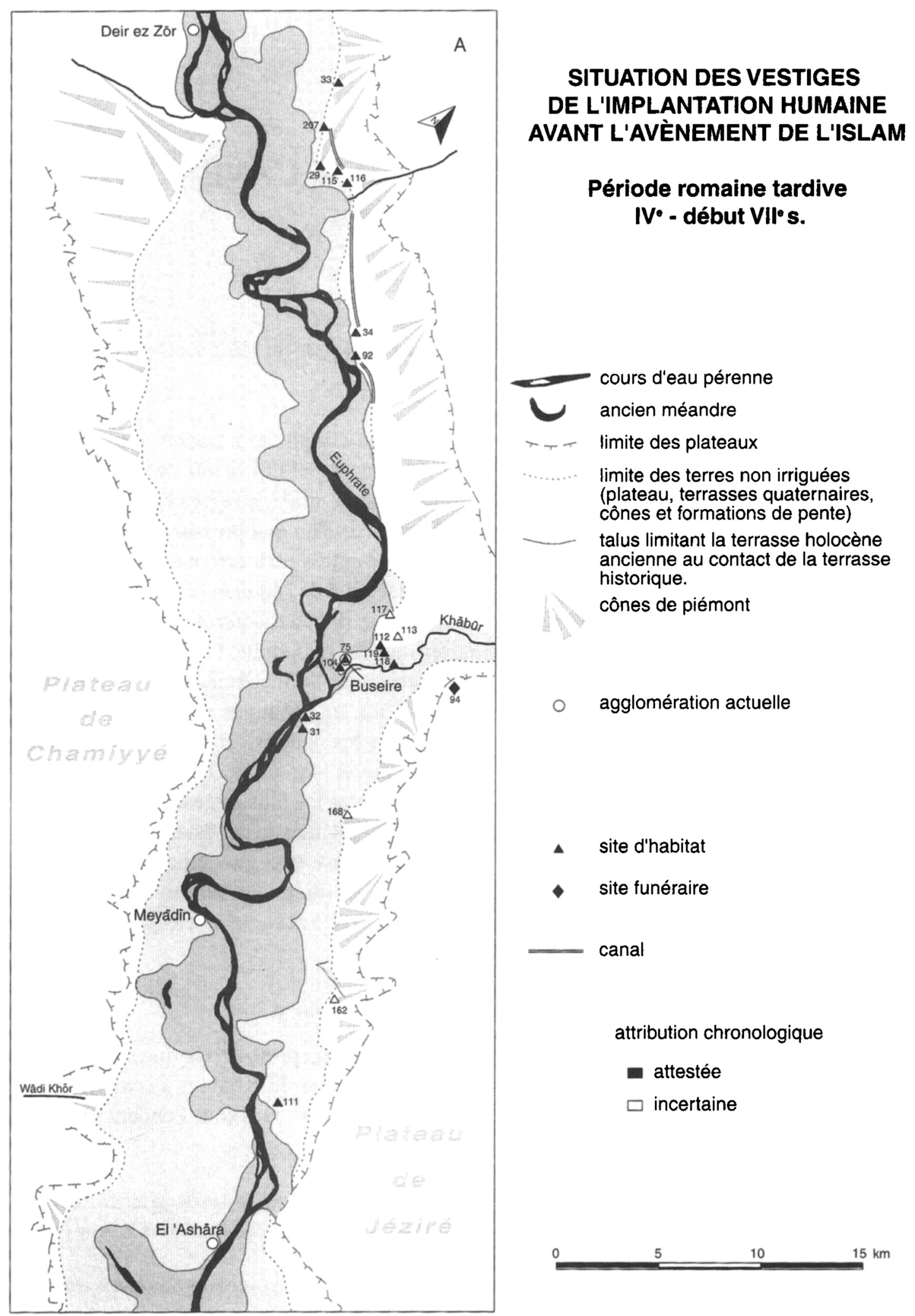

Fig. 1 Settlement in the middle Euphrates valley, below Deir ez-Zor, late Roman period; from Berthier, Peuplement, p. 16. 


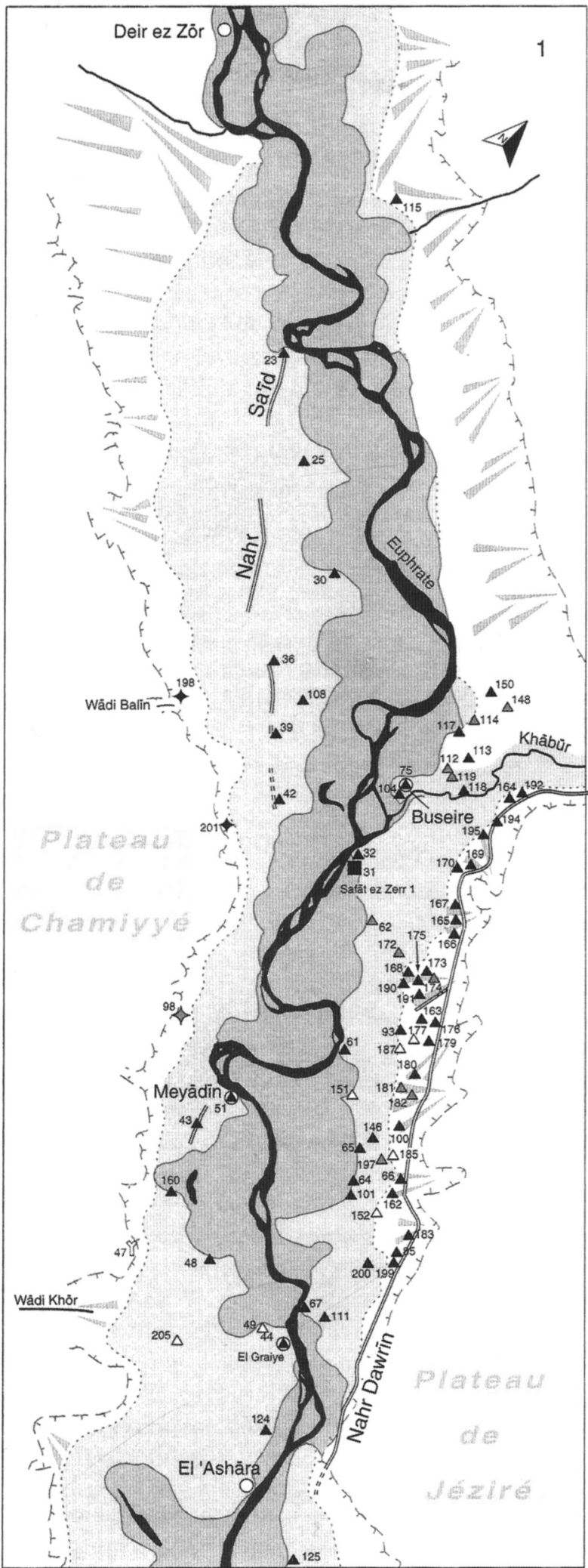

Carte E - Période Ib
$2^{\mathrm{e}}$ moitié du VIIII - IX $\mathrm{X}$.

DYNASTIE ABBASSIDE

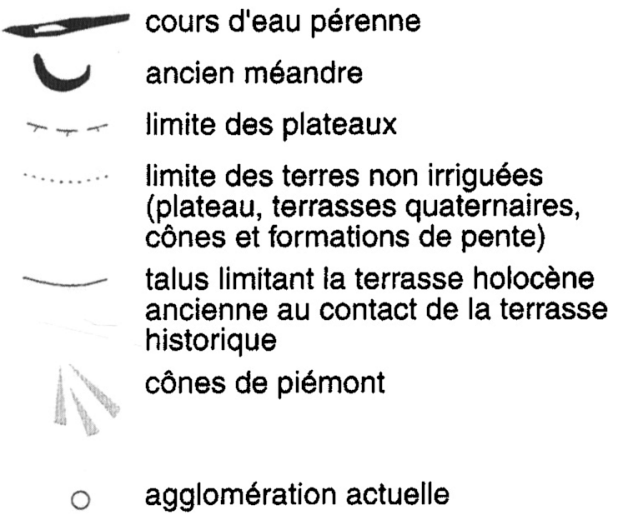

(1) site urbain

- site d'habitat rural

- site d'habitat saisonnier

- fortin, forteresse

$\checkmark$ mosquée

canal

canal (tracé supposé)

attribution chronologique

- attestée

- probable

$\square$ incertaine

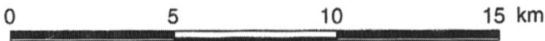

Partie 1 - Secteur amont : Deir ez Zõr - El ‘Ashāra.

Fig. 2 Settlement in the middle Euphrates valley, below Deir ez-Zor, ${ }^{\mathrm{c}}$ Abbasid period; from Berthier, Peuplement, p. 182. 


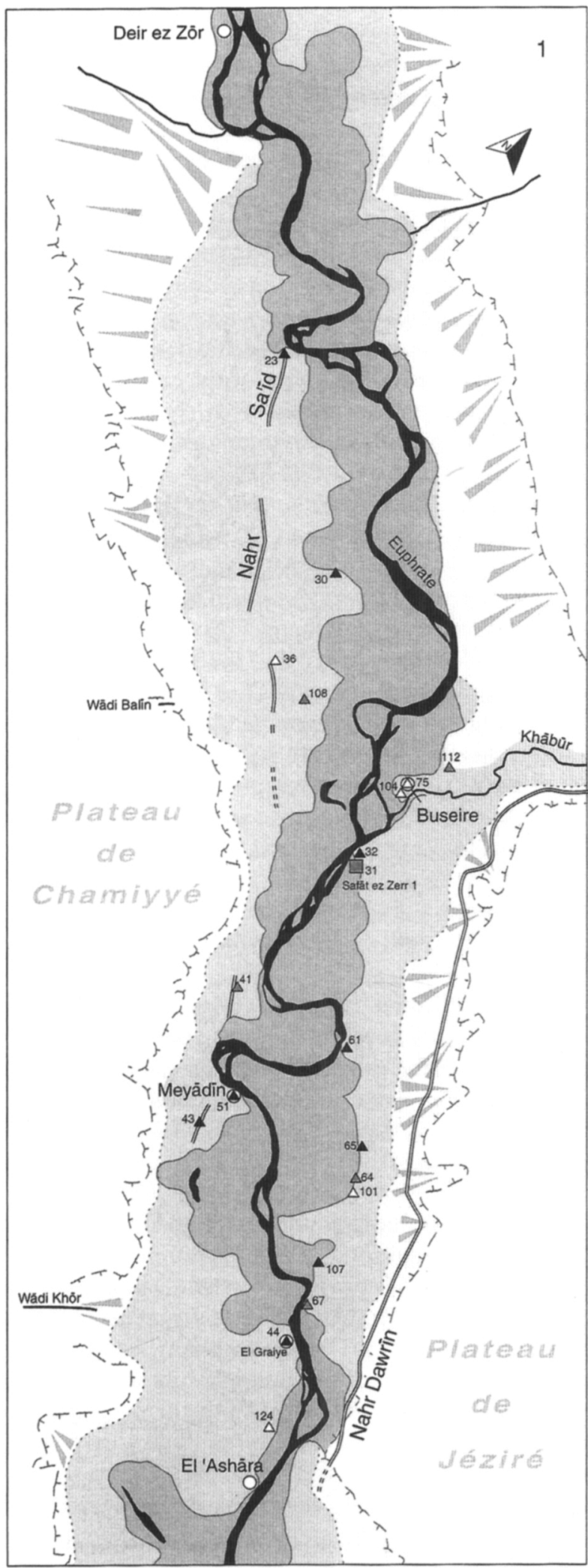

\author{
Carte F - Période II \\ $X^{\ominus} s$.
}

DYNASTIE HAMDANIDE

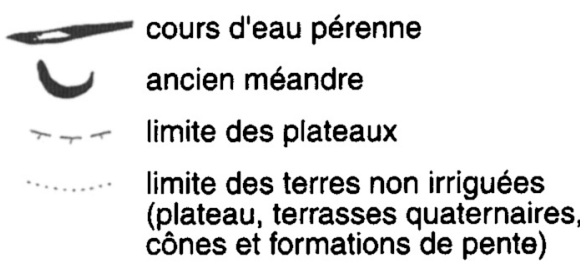
cônes et formations de pente)

talus limitant la terrasse holocène ancienne au contact de la terrasse historique

cônes de piémont

- agglomération actuelle

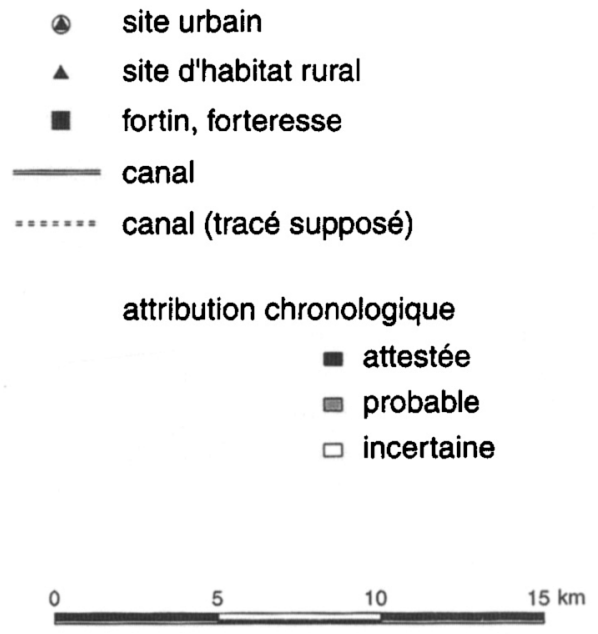

Partie 1 - Secteur amont : Deir ez Zōr - El ‘Ashära.

Fig. 3 Settlement in the middle Euphrates valley, below Deir ez-Zor, Hamdanid period; from Berthier, Peuplement, p. 184 
of small sites. The picture in the upper section, however, was very different. Here there were two major irrigation projects with rather different profiles and histories.

The lower one was based on the Dawrin canal system. The Dawrin was drawn not from the Euphrates, but from the lower valley of its tributary, the Khabur, which flows into the main river from the north. Much of the length of the canal can still be traced. It flowed from the Khabur and was led along the main valley of the Euphrates for about $130 \mathrm{~km}$. The channel was usually between nine and eleven metres wide ${ }^{93}$ and probably fairly shallow, only about one metre in depth.

It appears that the only major settlement in the area in the pre-Islamic period was the Roman frontier fortress of Circesium (Arabic Qarqisiya), which lay immediately upstream from the confluence of the Khabur and the Euphrates. This represented the furthest outpost of Roman and Byzantine control in the Euphrates valley. Beyond that must have been a sort of no-man's land where lack of security made agriculture hazardous, if not impossible. The Muslim conquests changed this strategic position entirely. From being a frontier war zone, the valley of the middle Euphrates became a main highway between two important provinces of the same empire.

There had been a canal along at least part of the course of the Dawrin canal in the third and second millennia BC but it seems to have fallen out of use after that. We have no specific historical record of the digging of the Islamic-period canal but al-Tabari records that the Umayyad caliph Hishām b. ${ }^{c}$ Abd al-Malik (r. 105-125/724-43) was given lands known at Dawrin as a qați $a$ before becoming caliph. The land was at this time deserted (kharāb) and he asked a secretary called Dhuwayb, who was working with him, what should be done. Dhuwayb replied by asking him what he wanted in exchange for the land and Hishām said, "Four hundred dinars." Dhuwayb then entered "Dawrin and its villages" in the diwans (presumably in his own name) and made a vast amount of money out of developing the land. When Hishām became caliph, he refused to give Dhuwayb a job and banished him from Syria because of the way in which he had exploited his position. ${ }^{94}$ If this story (which is told to illustrate Hishām's notorious carefulness with money rather than the process of agricultural development) has any truth in it, it suggests that the development of Dawrin formed part of a whole group of large-scale irrigation projects in the Euphrates valley undertaken by the sons of ${ }^{\mathrm{C}} \mathrm{Abd}$ al-Malik, including that of his brothers Maslama at Bālis and $\mathrm{Sa}^{\mathrm{T}} \mathrm{i} d$ just up river from Dawrin. It also shows how an entrepreneur like Dhuwayb could make a fortune from it. The last Umayyad caliph seems to have constructed the fortress still known as Marwaniya in the area and used Dawrin as a staging post for the army of twenty thousand men led by Ibn Hubayra on its way to conquer Iraq in $127 / 744-45 .^{95}$

Archaeological evidence, not from the canal itself but from the seventeen or so villages which grew up along its course, also suggests that the canal was developed in the later Umayyad period. It continued to be maintained in ${ }^{\mathrm{c}} \mathrm{Abb}$ bsid times with the number of settlements increasing. The canal itself was dredged on at least one occasion. By the year 900 , however, the canal seems to have been abandoned and large-scale irrigation in the area had ceased. Qarqisiya, which had been an important fortified city in Umayyad times, was gradually deserted and its role as the most important urban centre in the area was taken over by Rahba, upstream from the Dawrin canal.

The history of the Dawrin canal project raises important issues about the exploitation of land and attitudes to landowning and we can perhaps draw a few general conclusions. This area of the Middle Euphrates valley was on the frontier between the Roman and Persian empires and it seems that the only major settlement in immediately pre-Islamic times was the Roman military outpost at Circesium. The area was developed for agriculture by the Umayyad prince Hishām, probably in the second decade of the eighth century. This was a period when members of the ruling family were investing heavily in qata $\bar{l}^{c}$ as a way of boosting their income and political status. With the coming of the 'Abbasids, most of these lands were given to members of the new ruling family but we have no information about the ownership of the Dawrin canal area. As noted, the last Umayyad caliph Marwān b. Muhammad (127-32/744-50) had developed a fortress there and it may well be that

\footnotetext{
${ }^{93}$ Berthier, Peuplement, 33

94 al-Tabari, Ta'rik h ii 1735 . This seems to be the most likely interpretation of the anecdote. Hillenbrand's translation (The History of al-Tabari xxvi: The Waning of the
}

Umayyad Caliphate [Albany, 1989] 77) makes no sense at all.

${ }^{95}$ al-Tabarī, Ta'rikkh ii 1895, 1909; Berthier, Peuplement $566-67$. 
"Abbasid caliphs themselves took it over and it formed part of the royal sawäfi. ${ }^{96}$ This was a period of continuing investment, the dredging of the channel for example, and increasing settlement. This must be connected with the foundation and phenomenal growth of Baghdad. As noted above, one of the reasons al-Manșūr gave for choosing the site of Baghdad was its closeness to the Euphrates from which the Sarat canal provided a direct link by water, which meant that "everything from Syria, Raqqa and the surrounding areas" could be brought to the city. ${ }^{97}$ The role of the Euphrates in the transport of provisions (mira) is stressed in other passages. ${ }^{98}$ The subsequent development of Raqqa and the increasing importance of the river route between Raqqa and Baghdad, effectively the twin capitals of the early 'Abbasid caliphate, must have increased the value of these lands considerably.

In the ninth century, the capital moved to Samarra, which was not connected to the Euphrates by a direct water link, and Raqqa ceased to be used by the caliphs. By the end of the century, much of the Jazira was under the control of the Hamdanids and the ravages of the Qaramita at the beginning of the tenth century seem to have dealt a final blow to the prosperity of the area. With the drying up of the great urban markets and the continuing security problems, there was no incentive for continuing the massive investment necessary for maintaining the Dawrin canal. Those villages which survived did so on the basis of subsistence agriculture or by supplying the modest needs of the little town of Rahba. The remarkable development and collapse of this area can be seen as a direct consequence of its economic integration into the wider Muslim empire, a sort of Islamic globalization. When circumstances changed, the pattern of settlement and farming returned to what must have been its more usual and natural state.

Further up the river, on the west or Syrian side, Berthier's team investigated the Nahr Sa'id or $\mathrm{Sa}$ 'Td canal system. This was in many ways similar to the Dawrin canal, both in history and function, but at least parts of it were in use over a much longer period. According to al-Balādhuri, the area was presented by the caliph al-Walīd b. 'Abd al-Malik (86-96/705-715) as a qați $a$ to his brother

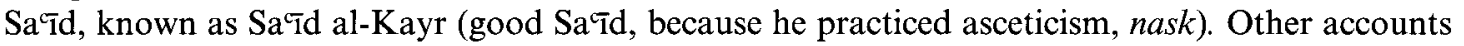
ascribe the gift to ${ }^{\mathrm{C}} \mathrm{Umar}$ b..$^{\mathrm{c}} \mathrm{Abd}$ al- ${ }^{\mathrm{c}} \mathrm{Azīz}(99-101 / 717-20) .{ }^{99} \mathrm{He}$ caused the canal to be dug in an area which had previously been a jungle (ghayda) infested with lions. Berthier doubts the historicity of this account, citing the absence of identifiable Umayyad material along the course of the canal, ${ }^{100}$ but, as she acknowledges in other cases, this may not rule out the Umayyad origins of the canal. ${ }^{101}$ Two other considerations suggest that the canal known as $\mathrm{Nahr} \mathrm{Sa}^{\top} \mathrm{id}$ may indeed have been the work of the Umayyad prince of that name. The first is that Sa'̄ was a comparatively obscure member of the ruling family, not a man about whose achievements legends grew up; if the canal had been ascribed to Hishām, we might have more reason for scepticism. The second is that the canal is mentioned by name in a narrative of military events in the reign of Marwān b. Muhammad. ${ }^{102}$

The Nahr $\mathrm{Sa}^{\top} \mathrm{id}$ seems to have been in use through the second half of the second/eighth and the whole of the third/ninth centuries. As in the case of the Dawrin canal, there is almost no evidence of activity in the fourth/tenth century but, in contrast to the Dawrin, it is clear that at least some sections of it were repaired in the eleventh century and remained in use until the early fourteenth. The canal itself was a gravity-irrigation canal, that is, its channel ran above the level of the fields which it irrigated. ${ }^{103}$ The archaeological evidence suggests the fields it serviced lay between the canal and the Euphrates river itself and that it formed a barrier, or at least a demarcation between the pastoral lands on the west side and the irrigated lands to the east. ${ }^{104}$

Apart from the old Byzantine fortress at Qarqisiya and the Marwaniya there were few major settlements along the Dawrin. Along the $\mathrm{Nahr} \mathrm{Sa}^{c} \mathrm{id}$, however, among the fourteen identified habitation sites were a number of quasi-urban settlements, one of which, Tell Mohasan, built on a Middle Bronze age tell, had an area of $900 \times 700 \mathrm{~m}$ - though not all of this may have been occupied

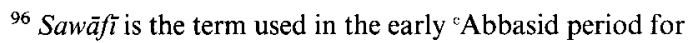
lands held by the caliph.

${ }^{97}$ al-Tabarī, Ta'rīkh iii 272.

98 al-Tabarī, Ta'rīkh iii 275, 276.

${ }^{99}$ al-Balādhurī, Futūh 179; Ibn Sallam, al-Amwāl para. 700; see also Rousset in Berthier, Peuplement 566.
}

\footnotetext{
${ }^{100}$ Berthier, Peuplement 166.

${ }^{101}$ Cf. Berthier, Peuplement 41.

102 al-Tabarī, Ta'rīkh ii 744-50.

${ }^{103}$ Berthier, Peuplement 101.

${ }^{104}$ Berthier, Peuplement 106.
} 
continuously. Two other such settlements were investigated by the archaeologists. Tell Guftan, which may have been the mediaeval Fam Nahr Sa ${ }^{\top} \mathrm{id}$ (Mouth of the $\mathrm{Sa}^{\top}{ }^{\top} \mathrm{d}$ Canal) had pottery which could be dated to the late eighth century in its lowest strata. ${ }^{105}$ At Tell Qaryat Medad, the earliest ceramics recovered from the limited sondages were dated to $c .840 .{ }^{106}$

Both canals and the associated settlements show clearly the massive investment in irrigation and the consequent expansion of agricultural activity in the eighth and into the ninth century, and both show the collapse of the canal systems and the depopulation of a number of sites at the beginning of the tenth. Such growth was clearly related to the estate policies of the members of the Umayyad family and, after 145/762, the growth of Baghdad as a major market for agricultural produce.

This development was a process which began in the Umayyad period but reached its fullest extent in the first ${ }^{\mathrm{C}} \mathrm{Abbasid}$ century. Interestingly, the archaeological record is complemented by the written sources. Al-Balādhurī describes how these canals were constructed by members of the ruling family in the first half of the eighth century. This area of the Euphrates valley had not been farmed extensively in Roman or Byzantine times, probably because it lay in a very exposed position straddling the frontier between the Roman and Sasanian empires. The effective abolition of the frontier after the Muslim conquest opened up this area to agriculture, though it did require active investment to allow it to reach its full potential. This agricultural boom was comparatively shortlived. By the end of the tenth century much of the canal system was dry and many of the villages deserted.

Another aspect of the development of this area can perhaps be seen at the site of Madinat al-Fār on the Balikh river, a tributary of the Euphrates. ${ }^{107}$ This site has been convincingly identified by the excavator, C.-P. Haase, with the place known to the Muslim geographers as Hisn Maslama or Maslama's castle, said to have been founded by Maslama, a son of the caliph 'Abd al-Malik, who died in about 120/738-39. He was famous as a leader of Muslim raids into Byzantine Anatolia but also appears as sponsor of irrigation projects at Bālis on the Euphrates and, as we have seen, in Iraq. The initial settlement seems to have been a square enclosure about 330 metres on each side with walls, a moat and four gates, one in the middle of each side. It was, to all appearances, a classic Umayyad qașr plan. In a second stage, the qașr was rebuilt, the rooms divided up, and new walls constructed of a much less regular fabric. At the same the settlement was massively extended to the south. This southern area was not planned in the same way: the dwellings were more dispersed and the wall which seems to have protected at least part of it was irregularly planned and poorly built.

The chronology of this settlement is not entirely clear. Umayyad coins and a little ceramic have been found in the original square enclosure but the southern extension has only yielded 'Abbasid material similar to that found in nearby Raqqa. The evidence peters out after 860 and there is no evidence of continuous occupation into the tenth century. Haase has seen this site essentially as a military base for expeditions on the northern frontier but I would like to propose an alternative or complementary interpretation. The square enclosure was indeed developed by Maslama, probably as a military base and residence for some of his numerous entourage: it was, then, a typical Umayyad qassr in both form and function. After the ${ }^{\mathrm{c}}$ Abbasid revolution, the settlement benefited from the expansion of agriculture in the Jazira, which can be linked to the development of Baghdad and Raqqa as major cities. What had been a princely residence now became an essentially commercial centre. The old walls were breached and new settlers built their houses to the south. They were farmers, grain merchants and general traders. The city remained prosperous only as long as the market for its produce existed; when circumstances changed, it was deserted and never subsequently inhabited.

The impression that the expansion of Hisn Maslama was not an isolated example and that the early ${ }^{\mathrm{c}} \mathrm{Abbasid}$ period was one of more general prosperity in the Balikh river valley is reinforced by

${ }^{105}$ Berthier, Peuplement 109.

106 Berthier, Peuplement 127.

${ }^{107}$ See C.-P. Haase, "Madīnat al-Fär: the regional late antique tradition of an early Islamic foundation" in Continuity and Change in Northern Mesopotamia from the Hellenistic to the Early Islamic Period, ed. K. Bartl and S. R. Hauser (Berlin, 1996) 165-71; C.-P. Haase, "The excavations at Madinat al-Fār/Hişn Maslama on the Balikh road" in Muslim Military Architecture in Greater Syria, ed. H. Kennedy (Leiden, 2006) 54-60. 
Karin Bartl's survey of the valley. ${ }^{108}$ As in the Euphrates-valley sites surveyed by Berthier et al., there is very little material evidence from the Umayyad period. In contrast there is a large volume of ceramic evidence from the early ${ }^{\mathrm{c}} \mathrm{Abbasid}$ period between the eighth and tenth centuries. Settlement in the early Islamic period was twice as dense as it had been under Byzantine rule. Most of these settlements were very small: seventy out of the eighty showing evidence of certain or probable settlement in the early Islamic period were under five hectares. It was a countryside of individual farmsteads and hamlets. The most important centre was Hisn Maslama at one hundred hectares. As with the Euphrates-valley settlements there is very little evidence of either new or continuing occupation in the tenth and eleventh centuries. In common with other commentators, Bartl sees this apparent boom as the result of the political and military activities of the ${ }^{\mathrm{c}} \mathrm{Abbasids,} \mathrm{making} \mathrm{Raqqa}$ their capital and using the Balikh valley as a major route between there and the Byzantine frontier. There may well be some truth in this picture but it can also be argued that this settlement was essentially an agricultural boom generated by the emergence of huge new markets for grain in Raqqa and Baghdad. The Balikh river valley, comparatively well watered and with good river communications, was ideally placed to take advantage of these conditions. The fact that most of the settlements were small and unfortified and that at Hisn Maslama, the only site where there is any evidence of fortifications, the walls of the old qașr were demolished to allow the settlement to expand, all suggest that agriculture, not strategic planning, was a more likely source of this prosperity.

\section{Conclusion}

The sources, both textual and archaeological, point to an enormous amount of agricultural development in the Tigris and Euphrates valleys and the Sawad of Iraq in the Umayyad and 'Abbasid periods. This led to lands being brought under cultivation in some areas which have not really been exploited before or since at any time in the longue durée of Mesopotamian agriculture. This agricultural boom lasted for a comparatively short period. It began in some areas immediately after the Muslim conquests of the 630s and early 640s, but by the beginning of the tenth century it had come to a halt and many of the lands which had been so painstakingly reclaimed were being deserted. The growth happened at different times in different places: the agricultural developments in the Basra countryside were essentially a phenomenon of the period of the Rashidun and Umayyad caliphs. The developments in the Euphrates valley began in the late Umayyad period and continued well into ${ }^{\mathrm{C}} \mathrm{Abbasid}$ times. In all areas, however, the tenth century saw the decay of these systems.

Before trying to establish the reasons for this collapse, some important points must be borne in mind. The agricultural expansion was the product of a number of different circumstances which came together at this time. Of the four factors permitting this economic growth which were suggested at the beginning of this paper, the flow of the rivers and the potentiality of water transport were permanent features of the environment, although of course the irrigation systems were not. The early Islamic fiscal system, the urban markets it generated and the security of landholding, on the other hand, were conditional on the survival of the early Islamic state structure and when the structure collapsed, they vanished.

This paper is not the place in which to examine the reasons for the vicissitudes of the caliphal government in the late ninth and early tenth centuries, ${ }^{109}$ but a few points should be stressed. The feeding of Baghdad was a precarious business and when supplies from outside were interrupted the effects were catastrophic. In 334/946, when, as mentioned above, supplies were not reaching the city from the Jazira,

Prices rose so high that people had absolutely no bread and ate the dead, or grass or any creature that had died a natural death, or carrion. When a horse dropped dung, a number of people collected and searched the dung for barleycorns to pick out and eat. Cotton-seed would be taken, moistened with water and spread on an iron plate, which was then put on a fire until it was dry and the seed was then eaten; this produced tumours in the intestines from which most of the eaters died and the survivors looked like

${ }^{108}$ The results are conveniently summarized in K. Bartl, "Balih Valley Survey: Settlement of the late Roman/early Byzantine and Islamic period" in Continuity and Change, ed. Bartl and Hauser, 333-48.

${ }^{109}$ On which see D. Waines, "The third-century internal crisis of the "Abbāsids", Journal of the Economic and Social History of the Orient 20 (1978) 282-303. 
corpses. Men, women and children would stand on the highroad perishing of famine and crying. "Hunger, hunger," until they died. If anyone found a little bread, he would hide it under his clothes, else it would be snatched from him. So many were the corpses that they could not be buried in time and the dogs devoured their flesh. The poor migrated in vast numbers and continuous lines to Basra to eat dates and most of them perished on the road; those of them who reached the place died after a short time. A woman of the Hāshimite family (that is the family of the Prophet) was found to have stolen a child and baked him alive in an oven. She had partly eaten him and was seized eating the remainder; she was put to death. ${ }^{110}$

This is the first account of a major famine in Baghdad and it is significant that it was caused in large measure by the interruption of grain supplies from the Jazira.

A major problem was that the Jazira became politically detached from Baghdad under rule of the Hamdanid dynasty. This was a gradual process of disengagement rather than a single dramatic move, but by $335 / 946$ the Hamdanids effectively ruled over the Middle Tigris and Euphrates valleys from Tikrit north. Under the terms of the treaty which established this, the Hamdanid ruler Nāşir al-Dawla was to send no revenue to Baghdad but he was to send plentiful provisions (al-mira) on which no tax (durayba) was to be paid (to Nāşir al-Dawla presumably). ${ }^{111}$ The treaty may never have been implemented because hostilities between the two sides soon flared up again but it shows the importance that the Buyid ruler Mucizz al-Dawla and the Baghdad authorities attached to supplies from the Jazira. From the comment about taxation, it would seem that the Hamdanid was asked to allow free trade rather than agreeing to pay tribute in kind.

As an afterthought, it should perhaps be noted that the system allowed the growth of extremely large cities and this urbanism had a profound effect on the development of Arabic and Islamic culture. Baghdad in its heyday was a city which supported a critical mass of literate people. It allowed, perhaps for the first time in human history, the emergence of a genuine book trade, and became an environment in which an author could write a book and hope to sell enough copies to make a living rather than being dependent on private wealth or on the patronage of a ruler or religious institution.

\section{Bibliography}

\section{Primary sources}

al-Balādhurī, Ahmad b. Yahyā, Futūh al-buldān, ed. M. J. de Goeje (Leiden, 1866).

al-Balādhurī, Aḥmad b. Yahyā, Ansäb al-ashräf iv pt a, ed. M. Schloessinger (Jerusalem, 1970).

Ibn Hawqal, Abū'l-Qāsim, Kitāb șürat al-ard, ed. J. H. Kramers (Leiden, 1939).

Ibn Sallām, Abū cUbayd b. al-Qāsim, Kitāb al-amwāl, ed. M. K. Haras (Cairo, 1975); trans.: I. A. K. Nyazee, The Book of Revenue (Reading, 2002).

al-Iștakhrī, Ibrāhīm b. Muhammad, Al-Masālik wa'l-mamālik, ed. M. J. de Goeje (Leiden, 1927).

Massignon, L. "Explication du plan de Basra", Westöstliche Abhandlungen R. Tshudi (Wiesbaden, 1954).

Miskawayh, Abū 'Alī, Tajārib al-umam, ed. H. F. Amedroz and D. S. Margoliouth (3 vols., London, 1921).

al-Tabarī, Muhammad b. Jarīr, Ta'rīkh al-rusul wa'l-muluk, ed. M. J. de Goeje et al. (3 vols., Leiden, 18791901).

Yāqūt al-Hamawī, Mucjam al-Buldān, ed. F. Wüstenfeld (4 vols., Leipzig, 1866-73).

Yūsuf, Abū, Kitāab al-kharājj, trans. A. Ben Shemesh (Leiden, 1969).

\section{Secondary sources}

Adams, R. McC. The Land behind Baghdad (Chicago, 1965).

Adams, R. McC. Heartland of Cities: Surveys of Ancient Settlement and Land Use on the Central Floodplain of the Euphrates (Chicago, 1981).

Adams, R. McC. and H. J. Nissen, The Uruk Countryside: the Natural Setting of Urban Societies (Chicago, 1972).

Bartl, K. Frühislamische Besiedlung im Balih-TallNordsyrien (Berlin, 1994).

Bartl, K. "Balih Valley Survey. Settlements of the late Roman/early Byzantine and Islamic period" in Continuity and Change in Northern Mesopotamia from the Hellenistic to the Early Islamic Period ed. K. Bartl and S. Hauser (Berlin, 1996) 333-48.

Berthier, S. et al., Peuplement rural et aménagements hydroagricoles dans la moyenne vallée de l'Euphrate, fin $V I I^{e}-X I X^{e}$ siècle (Damascus, 2001). 
Bianquis, T. "Rahba et les tribus arabes avant les croisades", Bulletin d'études orientales 41-42 (1993) 2352.

Donner, F. M. The Early Muslim Conquests (Princeton, 1981).

Haase, C.-P. "Madinat al-Fār': The regional late antique tradition of an early Islamic foundation" in Continuity and Change in Northern Mesopotamia from the Hellenistic to the Early Islamic Period, ed. K. Bartl and S. Hauser (Berlin, 1996) 165-71.

Haase, C.-P. "The excavations at Madīnat al-Fār/Hịșn Maslama on the Balikh road" in Muslim Military Architecture in Greater Syria, ed. H. Kennedy (Leiden, 2006) 54-60.

Kennedy, H. The Armies of the Caliphs (London, 2001).

Kennedy, H. "Military pay and the economy of the early Islamic state", Historical Research 75 (2002) $155-69$.

Kennedy, H. "Caliphs and their chroniclers in the middle Abbasid period" in Texts, Documents and Artefacts: Islamic Studies in Honour of D. S. Richards, ed. C. F. Robinson (Leiden, 2003) 17-35.

Kennedy, H. "The decline and fall of the first Muslim empire", Der Islam 81 (2004) 3-30.

Kühne, H. "Zur historischen Geographie am Unteren Habur", Archiv für Orientforschung 26 (1979) 18195.

Lassner, J. The Topography of Baghdad in the Early Middle Ages (Detroit, 1970).

Morony, M. Iraq after the Muslim Conquests (Princeton, 1984).

Nelson, H. S. "An abandoned irrigation system in southern Iraq", Sumer 18 (1962) 67-72.

Popovic, A. The Revolt of African Slaves in the 3rd/9th Century (Princeton, 1998).

al-Qadi, W. "Names of estates in the state registers before and after the Arabization of the diwans" in Umayyad Legacies: Medieval Memories from Syria to Spain, ed. A. Borrut and P. Cobb (Leiden, 2010)

Salih al-c'Ali, "Khițaț al-Bașra", Sumer 8 (1952) 72-83, 281-303.

El-Samarraie, H. Q. Agriculture in Iraq in the Third Century A.H. (Beirut, 1972).

Waines, D. "The third-century internal crisis of the "Abbāsids", Journal of the Economic and Social History of the Orient 20 (1978) 282-303.

Wilkinson, T. J. Agricultural Landscapes of the Near East (Tucson, 2003).

\section{Hugh Kennedy}

SOAS, University of London

Thornhaugh Street

London WC1H OXG

hk1@soas.ac.uk 